GANADORES CONCURSO INSTITUCIONAL DE CUENTO CORTO LA U ES

TU CUENTO :

GALLINAZOS DE DIEGO FERNANDO MENESES BALLESTEROS

LA PERFECTA MARIANA DE BEATRIZ EUGENIA CAMACHO DE LONDOÑO 


\section{GANADORES CONCURSO INSTITUCIONAL DE CUENTO CORTO LA U ES TU CUENTO}

El Concurso Institucional de Cuento Corto $L a \boldsymbol{U}$ es tu Cuento, es un espacio para que los miembros de la Universidad Autónoma de Bucaramanga desarrollen sus habilidades creativas e intelectuales de manera lúdica, a través de la creación de un cuento inédito de su autoría. Además busca fomentar el hábito de la lectura y escritura en los jóvenes universitarios. Como se trata de una propuesta de los estudiantes de pregrado universitario, representados por el Consejo Superior Estudiantil busca reconocer los valores artísticos y culturales de los estudiantes.

En su primera versión, la premiación se llevó a cabo en el marco de la Feria del Libro U Libro 2017 el sábado 2 de septiembre. Como parte de la premiación y como reconocimiento a los estudiantes, la revista de la Facultad de Ciencias Sociales, Humanidades y Artes, LA T3RCERA ORILLA reproduce a continuación los cuentos ganadores en las dos categorías:

Categoría 1: Estudiantes de pregrado de la UNAB de primero a quinto semestre. Ganador: Diego Fernando Meneses Ballesteros con su cuento Gallinazos.

Categoría 2: Estudiantes de pregrado de la UNAB de sexto semestre en adelante. Ganadora: Beatriz Eugenia Camacho de Londoño con su cuento La perfecta Mariana. 

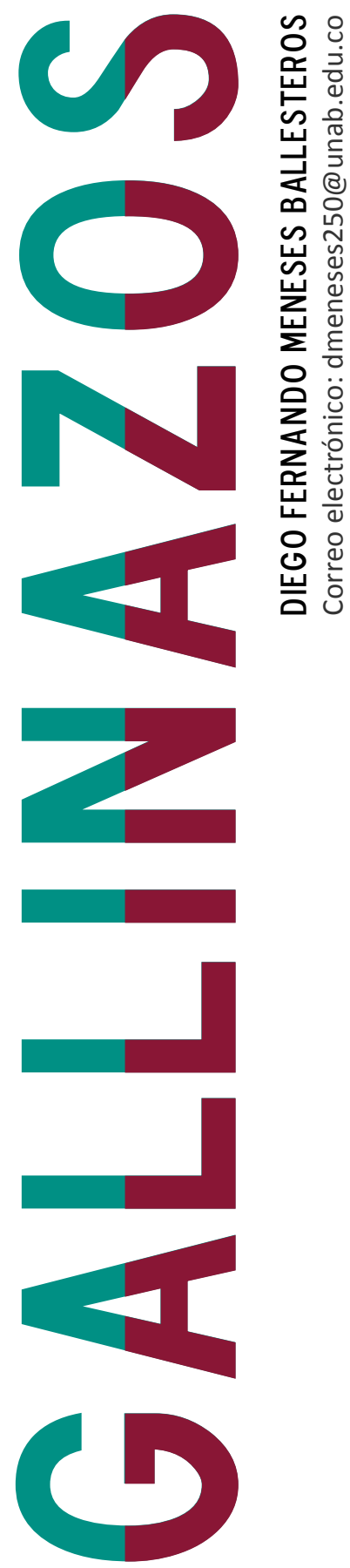

El jabón se resbaló de sus manos y por la profusa emisión de agua cálida de la regadera la espuma no se hizo esperar: cientos de burbujas empezaron a gravitar plácidamente hacia el cielo reflejando cada una imágenes del cuerpo de Santiago. El muchacho se reconoció en una pompa que flotaba frente a su rostro y se dejó llevar por ella: había un brillo lila en el contorno de la esfera y relámpagos de arcoíris sobre una superficie que parecía girar, expandirse y elevarse. Un juego de sucesiva clara luz y densa sombra se mezcló rudamente con al vapor que ascendía, cuando de repente ¡Pop! Santiago estalló. En la caída su cabeza se estrelló contra la pared y luego con un golpe seco dio con su cuerpo en el piso. Un hilo de sangre se mezcló rápidamente con el agua caliente y con la espuma, y su vida empezó a correr hacia el desaguadero.

Pasaron varios minutos, los suficientes para que Mercedes, su madre, empezara a preocuparse por tanta agua desperdiciada. Primero gritó que qué pasaba con el agua, luego que cerrara la llave y luego ató cabos: Santiago estaba en plena adolescencia. Temió lo peor. Subió de inmediato y tocó la puerta indignada, "iSantiago ábrame la puerta inmediatamente! ¡Santiago!". Pero nadie abría, y el grifo permanecía en fuga. Un fuego la invadió, un sudor grueso empezó a descender por su rostro y todo su cuerpo empalideció. Como pudo arrojó la puerta al suelo y las burbujas se agitaron con el ventarrón. Al entrar, observó el cuerpo de Santiago tendido sobre el azulejo y todo cubierto de espuma. Sintió un hielo agudo atravesar su espinazo y se desmayó. Su cabeza golpeó el lavamanos, golpeó la pared, golpeó el suelo, y un hilo de sangre azulada, gruesa, lentamente empezó a deslizarse y a ramificarse buscando, también ésta, aquél oscuro e infecto agujero.

Juana, la vecina, escuchó el grito que Mercedes arrojó cuando vio a Santiago muerto. Pero no pensó. No quiso. Sin embargo, tanto y tan profundo silencio la sorprendió al cabo de un rato. Dejó la cuchara de la sopa en la olla, elevó los ojos al techo como indagando, se secó las manos en el faldón y salió hacia la casa vecina.

\section{-iSeñora Mercedes!}

Silencio.

\section{-¡Señora Mercedes!}

De nuevo, nadie contestó. Solo el correr del agua y la sangre hacia esa boca que succionaba saboreando lentamente su alimento.

\section{-iSantiago! Exclamó desesperada.}

Tomó un segundo, tres. Mientras estaba sola frente a la puerta, un viento suave acarició con calma su rostro, le desplegó el faldón. Ella se sintió tranquila. Ese silencio y esa profunda soledad le hicieron bien, y volvió a su casa cuando recordó que no le había bajado al fogón de la sopa.

Mientras tanto, en el interior de la casa de los Medina el agua continuaba su purificación. La sangre diluida se escapaba por entre las rendijas del caño. Por un buen instante de tiempo solo existió el sonido del agua cayendo mientras las miradas de Santiago y su madre, impotentes, se cerraban de a poco, húmedas, lubricadas. Santiago, 
un instante antes de morir, maldijo aquél jabón y sus burbujas -lo más parecido que conoció jamás a una mujer; Mercedes, en el mismo instante, observó a su hijo y lo amó por última vez: total, era su único hijo y agradeció -se sorprendió de hacerlo- a la vida poder haberlo visto convertido en hombre.

Cuál habrá sido el destino de esa sangre recorriendo los ignotos y putrefactos caminos del desaguadero lo desconozco. Así son ciertas cosas que permanecen en el misterio. En cuanto a las burbujas, una vez subió el calor de la tarde dejaron de elevarse para finalmente desaparecer por completo. Cuando cayó la noche, el agua se acabó de tan cansada y fría que estaba y no volvió a correr jamás.

Un mes después, la señora Juana no soportó más los gallinazos en el techo de la casa de doña Mercedes (no se sorprendió de no haberla visto más después de aquel alarido: al fin y al cabo no se caían bien, pero conservaban ese último, íntimo e infalible recurso de solidaridad femenina. La verdad, lo único que las unía eran sus maridos que habían trabajado en el mismo aserradero, pero Eugenio había fallecido tres años antes con una astilla clavada directo en la aorta y Alfredo había desaparecido. Días después lo encontraron rio abajo, flotando entre unas piedras moradas. Pero nadie se quiere acordar ya de esas tristezas).

Un olor excesivo a caño le fastidió el olfato en el preciso instante en el que se acercaba a la olla para olfatear esas verduras al calor. Rota, pues, esa paz de la cocina, se decidió de forma inquebrantable a ir a la casa vecina y averiguar lo que estaba pasando, si es que no se estaban dando cuenta de semejante escena de porquería, que qué era esto, por el amor de Dios.

Y una vez más estaba frente a la pueta y llamó.

Pero recordó que Santiago se acercaba en ese mismo momento (recién llegba de clases). Ambos habían quedado paralizados y no se atrevían a mirarse a los ojos. El muchacho, nervioso, como pudo abrió la puerta. Su madre salió a su encuentro, pero se sorprendió de ver a Juana en ese mismo instante. Algo incómoda la invitó a seguir, mientras el muchacho subía a su habitación, ya sin paz.

Resonó de nuevo en su cabeza aquel último grito de Mercedes y recordó todo aquel tiempo perdido entre ansias asfixiantes y desvelos lunares, y entendió que esa puerta cerrada, ese silencio y ese viento que acariciaba sus cabellos y revelaba sus facciones marchitas, eran el final de sus sueños de amor y hombre.

Bajó su cabeza resignada y regresó a la olla de la sopa que estaba esperándola, como todos los días, para recibir esas lágrimas que hacían la sazón un poco más sabrosa. "De todas formas", suspiró, "los gallinazos también deben cumplir su misión, como los recuerdos". 


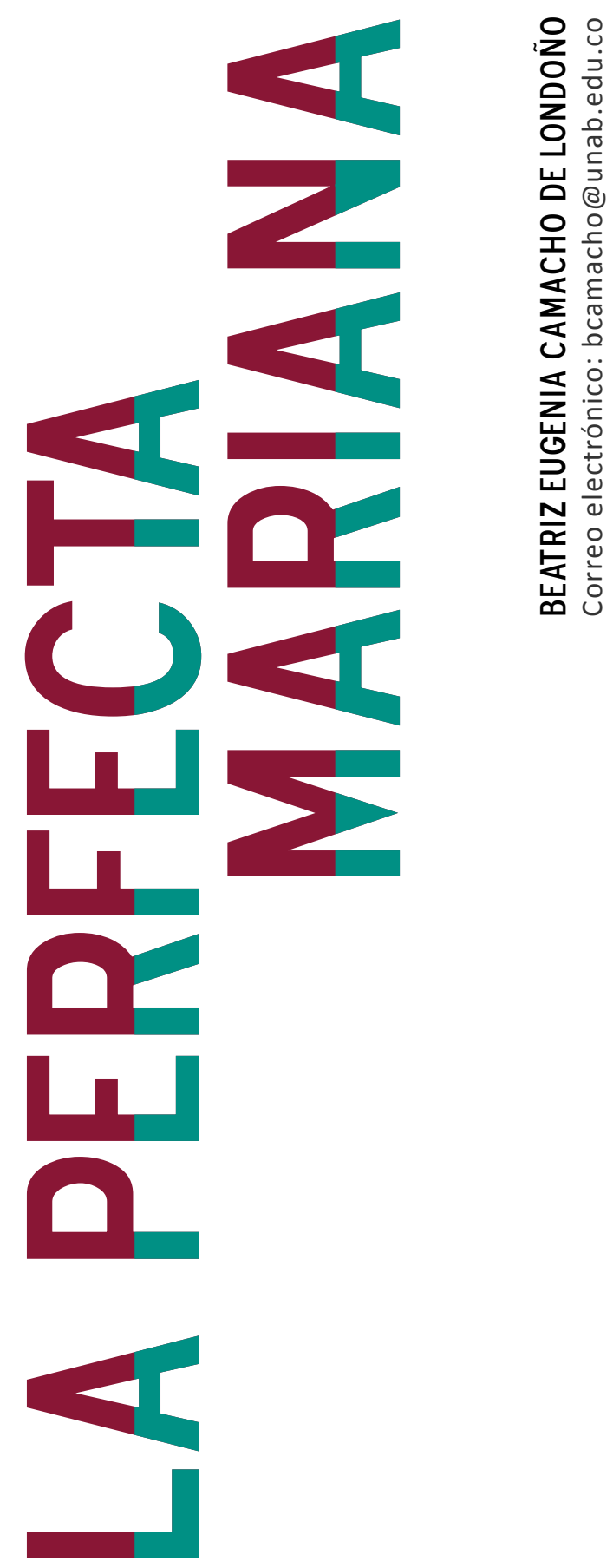

-A las seis te recojo y no me hagas esperar-le dice mirándolo.

Baja la cabeza asintiendo y sale del auto. Con dos dedos le envía un beso asomándose por la ventanilla. Camina apoyado con el bastón hasta la puerta del edificio. El celador de turno lo saluda con una inclinación de cabeza y lo hace seguir. Mariana no arranca el auto hasta que lo ve entrar. Conrado toma el ascensor y en el quinto piso se baja, llega a su oficina y llama por citófono a Purita, su secretaria. Ella entra con un cartapacio de papeles y los deposita a un lado del escritorio.

- ¿Hasta qué horas trabajaste ayer? -le pregunta Conrado.

-A las nueve terminé de pasar en limpio todas las demandas del edificio "Country Sur". Revísalas y me dices si tengo algún error... Anoche me quedé esperando tu llamada -le responde.

-No pude, tú entiendes.

Desde hace más de quince años la rutina es la misma. Se despierta a las seis de la mañana con el olor del cafecito puesto encima de su mesa de noche, al lado del diario. Lo toma y lee rápido los titulares. Observa encima de la silla de enfrente, la camisa blanca impecablemente planchada, el vestido azul de rayas colgado en una percha, el cinturón, la corbata, las medias, los interiores y los zapatos brillantes; lo necesario sin faltarle nada, para vestirse con elegancia después de tomar una ducha caliente; todo está a la mano para que no se moleste en buscar qué ponerse. Además, es inútil que quiera cambiar algo, aunque sea la corbata. Ya sabe a qué atenerse si lo hace. En el baño, los utensilios para la afeitada 
los encuentra en perfecto orden: la brocha de pelo de camello, el jabón fino, la navaja, la toalla caliente y la loción. Finalizado su arreglo personal, baja las escaleras con el periódico.

En el comedor lo espera un delicioso desayuno. Lo consume con rapidez mientras lee. Mariana hace la gimnasia con su instructor junto a la piscina. Al ver llegar a Conrado, da por terminada su clase, se pone una sudadera y abre la puerta del comedor. Saluda a su esposo, revisa su atuendo y le dice que está lista para llevarlo a la oficina. Tiene el tiempo justo para el viaje de ida y regreso sin alterar sus demás actividades. Un problema en la pierna derecha de Conrado, le impide manejar, después de un aparatoso accidente que sufrió hace quince años, en los que faltó poco para que perdiera la vida. Siempre está supeditado a que Mariana lo transporte al trabajo y por la tarde, lo retorne a casa. Ella se opone rotundamente a conseguirle un conductor; le repite continuamente que es su obligación cuidarlo y con el mayor gusto lo puede llevar y traer las veces que sea preciso y a donde necesite desplazarse. Conrado no le responde nada.

De lunes a viernes no varía el reglamento ni los horarios de la casa. Se asemeja más a una guarnición militar que a un hogar. En las tardes al regresar de la oficina invariablemente se prende el televisor, se ven las noticias y nada más porque a Mariana no le agrada ningún programa. Dice que es perder el tiempo y que la gente debe acostarse temprano. Conrado adora leer pero puede hacerlo solamente durante una hora porque a Mariana le molesta la luz para dormir.
En los últimos tres años, en varias ocasiones ha intentado salir solo de la casa. Puede hacerlo con el bastón sin problema alguno, pero ella se lo impide cariñosamente acompañándolo así fuera a comprar unos cigarrillos. Le permite que se fume dos, entonces Conrado debe salir al patio, fumárselos y volver a entrar rápido porque Mariana lo llama diciéndole por qué tanta demora.

Desde hace mucho tiempo las noches para Conrado se han vuelto insoportables. No puede voltearse en la cama porque despierta a Mariana; si se levanta, de inmediato lo percibe y comienza el interrogatorio de por qué está desvelado. Hacen el amor los sábados a las ocho y media, cada quince días, ni antes ni después. Es el momento más detestado por Conrado. Él nunca lo hace bien. Ella siempre tiene reproches y por más que se esfuerza, no sabe cómo complacerla.

Una noche, sentado en la sala leyendo el periódico, en pantuflas, a la espera de que esté lista la cena, observa que Mariana tarda mucho en el teléfono. Habla con una amiga que vive en el exterior y no puede interrumpirla por ser muy difícil la comunicación.

Conrado aprovecha para decirle por señas que va a comprar cigarrillos a la tienda de la esquina porque se le han terminado. Ella lo mira y como ve que no tiene zapatos, le dice que sí, que vaya en pantuflas porque es cerca, pero que no se tarde porque ya va a servir.

Han pasado ocho años y nada se sabe de Conrado. No volvió a la oficina. Purita tampoco. Mariana continúa indagando sobre su paradero. 